\title{
The Path of Professional Connotation Construction of Local Universities Against the Background of "Double First Class" Construction*
}

\author{
Jianxian Wang \\ Teaching Affairs Department \\ Huaiyin Normal University \\ Huai'an, China 223001
}

\author{
Weimin Zhang \\ School of Education \\ Soochow University \\ Suzhou, China 215123
}

\begin{abstract}
The construction of "double first-class" has set off a new wave of reform of specialty construction in Colleges and universities. The local applied-oriented universities cannot compete with the old famous universities in the first-class universities and the first-class disciplines, but they can find their own foothold in the first-class professional construction and the first-class undergraduate education. At the same time, we should use the east wind of "double first-class" construction, take the local social economy, industry and industry as the guidance, improve the quality of personnel training, plan the professional layout scientifically, improve professional accreditation, build professional brand, and form the core competitiveness of its own professional construction.
\end{abstract}

Keywords-"double first-class" construction; local universities; professional connotation construction

\section{INTRODUCTION}

Specialty and specialty construction is an important foundation for improving the quality and connotation of running a university. The level of specialty construction reflects the characteristics, level and future development advantages of a university. Having a number of specialties with distinctive brands will play a positive role in promoting the popularity and efficiency of colleges and universities. Over a period of time, due to the rapid development of higher education and the need of local colleges and universities to apply for postgraduates, the categories, quantity and quality of many local colleges and universities have been greatly improved ${ }^{[1]}$. However, the contradiction between the quality of university personnel training and social satisfaction demand has become increasingly prominent, the community to enhance the connotative development of colleges and universities, to improve the quality of graduate training is rising day by day! In the report of the Nineteenth National Congress of the Communist Party of China (CPC), the way to solve the problem is proposed,

\footnotetext{
*Foundation Project: Department of Education Humanities and Social Sciences Research Youth Foundation "Practical Research on the Integration of Entrepreneurship Education and Professional Education in American Colleges and Universities" (Project Approval No. 18YJC880130).

[Chinese classification number] G64 [Document identification code] A
}

which requires universities to deepen the integration of production and teaching, strengthen the cooperation between universities and enterprises, speed up the construction of first-class universities and disciplines, and realize the connotative development of higher education. The implementation of "quality engineering" and "connotation development" set off a new wave of professional construction reform in Colleges and universities. For local colleges and universities, they are also faced with rare opportunities and advantages, but also faced with severe shortcomings and threats. First-class universities and firstclass disciplines cannot compete with "two-class" universities, but can find their own foothold in first-class professional construction and first-class undergraduate education. To this end, local colleges and universities should take into account their own environment and conditions, strengthen top-level design, take practical measures to upgrade the professional construction in an all-round way according to the objective requirements of economic development.

\section{II. "DOUble FiRst Class" CONSTRUCTION PROMOTES LOCAL COLLEGES AND UNIVERSITIES TO ENHANCE THEIR PROFESSIONAL CONNOTATION}

General Secretary Xi pointed out in the report of the 19th National Congress of the Communist Party of China that quality determines the rise and fall of education. Quality is the lifeline of education work and we should vigorously promote the quality and efficiency of development. With the improvement of China's economic level and the expansion of the scale of colleges and universities, the competition among colleges and universities has changed from the number of schools to the quality of running schools. However, how to improve the quality of running schools? How to become a powerful country in higher education? On October 24, 2015, the State Council issued the "Overall Plan for Promoting the Construction of First-class Universities and Disciplines in the World" to provide the answer: to speed up the construction of a number of world-class universities and disciplines with Chinese characteristics as the core, to establish morality as the basis, to support innovation-driven development strategy, and to serve economic and social 
development as the guide. Universities and first-class disciplines! This clearly put forward the direction of the future development of higher education in China, and formally started the construction of "double first-class" higher education in China. Since then, the policy orientation, financial support, the expectations of the people, making the "two-class" construction in China's "985" and "211" and other high, elite, top-notch schools in full swing: 2016, the 13th Five-Year Plan of the People's Republic of China's national economic and social development, reiterated: improve the quality of education; improve university teaching The academic level and innovative ability have made some colleges and universities and a number of disciplines reach or approach the world first-class level; the report of the Nineteenth National Congress put forward the implementation of the "Six Excellence and One Top-notch Plan" version 2.0; and the work ideas and key points of the Higher Education Department of the Ministry of Education in 2018 are singing the theme of "first-class undergraduate, first-class professional, first-class talent training". However, we should be soberly aware that the "double first-class" construction for local colleges and universities, but it seems unattainable, whip less than. Due to historical reasons, local colleges and universities are far behind the "985" and "211" famous old schools in terms of time, scale, experience and resources. What should local colleges and universities do under the background of "double first-class" construction? This has become a common problem and challenge faced by all local colleges and universities. ${ }^{[2]}$ In our country, local colleges and universities have remarkable characteristics of locality, profession and technology in their orientation of running schools. The training target is mainly local applied talents. Their proportion and composition account for more than $90 \%$ of all kinds of colleges and universities in China, and they are the main body of higher education in our country. ${ }^{[3]}$ Therefore, local colleges and universities should take advantage of the "double-first-class" construction of the East wind, and actively strive to keep pace with the times, make waves and fight to find their own "double-first-class": with their own local, regional, industrial, applicationoriented, characteristic, brand, to create their own "first-class undergraduate education"; with the help of regional or similar colleges; The first-class local or regional professional ecological system, application specialty, special needs specialty, characteristic specialty, create their own "firstclass specialty" to form a first-class local university with unique core competitiveness. Therefore, local colleges and universities should be highly in line with the local social economy in terms of professional categories, quantity and structure, adopt diversification in running schools, build integration of production and teaching, school-enterprise coconstruction, highlight the characteristics of their own professional school-running, taking into account the balanced benefits of all parties. In a word, the first-class undergraduate education should take root in the market, take root in the society, and be higher than the market, higher than the society, and ultimately lead the society. To this end, local colleges and universities must once again emancipate their minds, reform thoroughly and make further breakthroughs in their work. On the basis of accurately understanding the development trend of higher education, we should further improve our understanding, unify our thoughts, change our ideas and promote ourselves, so that the reform will become the greatest driving force and the greatest dividend for Specialty Construction under the background of "double-first-class" construction.

\section{PROBLEMS EXISTING IN THE CONNOTATION CONSTRUCTION OF LOCAL COLLEGES AND UNIVERSITIES}

Facing the arrival of the era of "quality engineering", "connotation development" and "specialty as king", local colleges and universities should be conscious of the problems existing in the construction of their own professional connotation, face new opportunities and challenges, inquire into the pulse, offer good prescriptions, and bravely shoulder their historical responsibilities.(1) the ideological concept is lagging behind. Thought is the forerunner of revolution and the pioneer of practice. The rapid development of economy and society, the rapid progress of science and technology, and the new requirements of the society for the quality of personnel training require the local applied undergraduate colleges and universities to update their ideas in time. At the same time, the establishment, planning, construction and upgrading of specialties also need to be matched with it. Fit the educational concept ${ }^{[4]}$. During the 13th Five-Year Plan period, the state listed new policies and tasks for the integration of industry and education, professional certification and the reform of the college entrance examination system. The General Office of the State Council issued in December 2017 "Some Opinions on Deepening the Integration of Industry and Education", emphasizing the construction of professional clusters, improving the distribution of educational resources, and promoting the linkage between education and industry. "National Standard for Teaching Quality of Undergraduate Specialty in Universities and Colleges" has been promulgated formally, and "First-class Undergraduate, First-class Specialty and First-class Talents" has become an important task put forward by the National Conference on Education and the working points of the Ministry of Education. From the beginning of 2021, the major will be the most important factor for candidates to choose Colleges and universities, and the comprehensive arrangement of The famous will retire. Not only that, within the same university, specialty adjustment will no longer exist, and there will inevitably be a huge disparity between different majors. These reforms are directly pushing the ideological emancipation and upgrading of local colleges and universities. However, a considerable number of comrades in local colleges and universities are not sensitive to the new situation of social and economic development and have not fully realized the importance of professional construction. They do not have a good understanding of the rich concepts and connotations of the National Standard, the three-level professional certification, the reform of the college entrance examination system and the adjustment of the distribution of specialties in Colleges and universities. At the same time, from the perspective of stakeholder theory, because of the different values and interests, different stakeholders, such as schools, secondary 
colleges, teachers and other stakeholders, also have great differences in achieving the objectives of professional construction reform, and different stakeholders have certain interests. There is also the thought of waiting and dependence. (2) convergence of structural planning. The number, structure and planning of specialties in local colleges and universities should be based on the development of local regional economy and society. Since the founding of New China, the adjustment of specialty structure and planning in Chinese colleges and universities has also been based on meeting social needs. With the rapid development of local regional economy, local economic, industrial and industrial factors play a more and more important role in guiding the specialty construction and planning of local applied undergraduate colleges and universities. It also opens up a new growth point for specialty setup and specialty planning of local applied undergraduate colleges and universities, which is very conducive to the specialty construction of local colleges and universities in China. Near the local economic and social development, and through the local social market test to obtain professional sustainable development momentum, help and support. However, in the past period of time, due to the rapid development of higher education and the pressure of local universities to upgrade, some colleges and universities excessively pursue the "short, fair and fast" effect, often keen to excessive declaration of new majors, undergraduate colleges and universities declare more than 5000 new majors every year, and some local colleges and universities even "one-time declaration." Dozens of specialties "and" 61 colleges have declared 7 or more new specialties "[5]. Emphasis on quantity over quality, lack of foresight and operability in professional quantity, category and planning, obvious shortage of teachers, serious imbalance in the ratio of students and teachers in individual majors, serious lack of top-level design, effective coordination and resource integration, and no foundation for long-term development. Generally speaking, on the one hand, neglect of social investigation and research, personnel training and local social and economic development needs are disconnected, the setting of social needs are insufficient sunset specialty, on the other hand, the phenomenon of following the trend is widespread, lack of social needs of the rising sun specialty ${ }^{[6]}$. The homogeneity of specialty construction among local colleges and universities is serious, which leads to the repetition of specialty construction, the low quality of personnel training, the difficulty of students' employment, the lack of innovation and characteristics, and so on. All these make colleges and universities fall into a vicious circle. Strengthening the specialty setting and planning of local colleges and universities not only promotes local colleges and universities to better adapt to the development of local regional economy and society, but also conforms to the inherent requirements of higher education governance. It is also a valuable experience for the specialty construction of international colleges and universities. It can be seen that if local colleges and universities want to be invincible in the future competition, their professional connotation construction should not only be guided by social needs, but also be balanced, not blindly follow the trend. If you obey blindly and indiscriminately, you will inevitably lose your inherent characteristics, pick up the sesame and lose the watermelon. In addition, if the construction of specialty connotation in local colleges and universities is completely oriented by the local market demand, some specialties in some colleges and universities will face the situation of being weakened or even cancelled, leading to the defects of specialty construction in local colleges and universities. For local colleges and universities, the construction of specialty connotation should be paid more attention to, and should be constantly tapping the mutual promotion between local social needs and school specialty construction, not only to meet the local social and economic needs, but also to take full account of the current local social and economic needs are small, but the future potential value of a high degree of specialty for the local economy. The future development of the economic society reserves talents.(three) lack of distinctive features. The development of specialty characteristics is the key factor for the sustainable development of specialty, and it is also the core feature of the vitality of specialty. In order to seek the development of specialty characteristics, we must pay attention to the construction of characteristic teachers, characteristic teaching methods, characteristic education management, characteristic teaching conditions, cultivating characteristic students, and creating the advantages of specialty characteristics. On May 4, 2014, Xi Jinping also emphasized that China's world-class universities must have Chinese characteristics. Similarly, to run first-class local universities in China must have local professional characteristics. However, the current situation is not optimistic, local colleges and universities have no obvious professional characteristics and advantages, similar training objectives, similar curriculum system, backward training mode, lack of teaching resources platform, lack of information technology, poor classroom teaching efficiency, serious homogenization of development, national and provincial high-level professional construction projects The lack of professional certification and evaluation, which can show the quality of professional connotation construction, has not made a breakthrough. Even, many local colleges and universities have not set up brand professional consciousness, have not combined with the local economic development and historical advantages of colleges and universities to focus on "building" and "packaging" specialty, professional characteristics are not distinct. Through the investigation, it is found that the construction results of the same major in different colleges and universities are quite different: some local applied undergraduate colleges and universities can build it into a national-level specialty, while others are facing a situation of dying, and can only be abolished ${ }^{[7]}$. It can be seen that it is a long way to go to strengthen the development of local colleges and universities. In the new round of education reform and development, local applied undergraduate colleges and universities not only have no reason to retreat, but also have the courage to stand at the tide of reform, forge ahead, and strive to leave a glorious "professional mark of local colleges and universities". 


\section{The PATH OF PROFESSIONAL CONNOTATION CONSTRUCTION IN LOCAL UNIVERSITIES}

Under the background of "double-first-class" construction, the construction of specialty connotation in local colleges and universities should be student-centered, oriented by local social and economic needs, aimed at improving the quality of personnel training, scientifically plan the layout of specialties, improve the degree of specialty recognition and create a specialty brand ${ }^{[8]}$.(1) self check and plan professional layout scientifically. Know your enemy and know your enemy, and you will be victorious. Local colleges and universities to enhance the connotation of professional construction, first of all, to analyze their own shortcomings and defects, the right remedy. On the basis of regional economic and social development, the orientation of local colleges and universities and the practice of professional development, following the law of specialty construction, the law of talent cultivation and the law of students' growth and development, this paper makes an indepth investigation and study to find out the specific crux of the existing specialty structure of local colleges and universities, and takes students as the center and industry as the guide. To establish a harmonious pattern of professional development in terms of scale, structure, quality and efficiency for the future Local colleges and universities provide guidance and follow up for professional development.(2) scientific argumentation, optimizing and adjusting professional structure. Professional structure adjustment and optimization is the inevitable requirement of deepening the reform of higher education, the inherent need of scientific development and sustainable development of local colleges and universities, and it is of great significance to the survival and development of local colleges and universities. Local colleges and universities should take "appropriate scale, reasonable layout, structural optimization, sustained development" as the goal, adhering to the basic concept of "scientific positioning, highlighting key points, strengthening characteristics, creating brands", docking the industrial industries, according to the results of the local industry (industry) research, industry (industry) demandoriented, clear profession (industry). The core specialty and supporting specialty of the cluster construction should be completed, and the construction plan should be followed to guide the construction of the cluster and build a professional structure full of tension and sustainable development. According to the construction plan of specialty connotation, we should set up specialty establishment and planning management organization, invite relevant government departments, trades and enterprises to plan together and participate in the whole process, strengthen the attention and Research on the changes of local social talent market demand, and do a good job of local talent demand forecast together, so as to make a scientific demonstration on the basis of Advance the potential specialty of local social and economic development. At the same time, it is necessary to constantly adjust, modify, supplement and perfect the strategic plan of specialty setting in local colleges and universities, so as to realize the rationalization of specialty setting and planning. Specifically includes three aspects: first, to adapt to the local economic and social development, talent training objectives clearly positioned, training model distinctive features, training program feasible, adaptable, broad development of the sunrise profession, to actively encourage, support and increase investment and support, teaching resources can be allocated in priority, and indeed Secondly, efforts should be made to reform the old specialties with certain advantages in local colleges and universities, to meet the local market demand, to constantly update the personnel training mode, and to ensure that the old specialties are thoroughly upgraded and transformed on the premise of maintaining their own professional characteristics and fine traditions. Finally, we should boldly adjust or eliminate the sunset majors with low quality of personnel training, low employment rate and weak social recognition. By reducing capital investment, controlling enrollment or stopping enrollment, reducing the number of teachers, reducing the number of scientific research projects and other measures, let these underdeveloped sunset professional slowly abolished. At the same time, we should strengthen the construction of professional clusters and enhance the support degree of service places. In a word, local colleges and universities should adjust their majors dynamically to make the distribution of majors more reasonable, the structure of majors more optimized, and the quality of education and the efficiency of running schools more obvious $^{[9]}$.(3) enhance professional quality by means of professional assessment and certification. Professional evaluation refers to the evaluation of the expected objectives and results of the teaching process, which is an important part of the evaluation of higher education in China. Professional certification is a special certification carried out by the accreditation agencies for the Higher Vocational Majors offered by schools. The purpose is to ensure the quality of graduate training. Under the new normal condition of economic development, with the trend of scale and internationalization of higher education in China becoming more and more obvious, the classification and evaluation of colleges and universities has become an inevitable trend. At the same time, professional assessment certification has also become an important starting point for the construction of professional connotation ${ }^{[10]}$. To carry out professional evaluation and certification in local applied undergraduate colleges, on the one hand, it is necessary to establish and improve the mechanism and organization of professional evaluation and certification, and strive to ensure that the selfevaluation and self-construction of the institutes in which the major is evaluated can make the construction projects clear, the work content clear, the quality standards strict, the division of labor reasonable, the supervision and inspection in place, and ensure the local high quality. On the other hand, it is necessary to establish a scientific, reasonable and operational evaluation and certification index system. Local colleges and universities should take students, professional education output, professional graduates training quality and other teaching results as the starting point of professional evaluation and certification, and evaluate whether the setting of professional personnel training objectives is reasonable by the ability and accomplishment of the graduates, and further determine the attainment of professional ability on the basis of this. And professionally required teaching process. 
Engineering education certification is a common international and domestic professional certification because it conforms to the development trend of "result-oriented" higher education evaluation certification. Local colleges and universities can start engineering certification in an all-round way according to the project concept of "National Basic State Database of Colleges and Universities Teaching", "Assessment of Higher Education Learning Achievements"(AHELO) and the successful experience brought about by engineering education certification ${ }^{[11]}$ according to the study and training, self-evaluation of bid, centralized construction, campus certification, etc. Application preparation, specialist admission and continuous improvement of the seven-stage cycle of organizing certification preparation, while point-by-point, constantly improving other professional assessment certification. In 2018, the National Standard for Teaching Quality of Undergraduate Majors in Universities and Colleges was promulgated. Local colleges and universities should control the National Standard for Majors to achieve full coverage of all professional evaluation and certification.(4) building characteristic specialties to create professional brand in Colleges and Universities Specialty characteristics are the breakthrough point for local colleges and universities to win by small means and by weak means. It is also the breakthrough point for local colleges and universities to rise to a new peak and win by surprise. Faced with the new situation, new tasks, new missions and new stages of China's higher education, local colleges and universities want to achieve sustainable development in the competition of colleges and universities, we must create a "people without me, people with my excellent" professional brand, and break out of their own way. However, the specialty brand building of local colleges and universities should not be no Earthless wood, no source of water, it is more local colleges and universities in the reform of education and teaching and long-term professional construction process, on the basis of their own specialty, through the category of broadening or highlighting the strengthening of the function of a certain direction of the specialty, through continuous summary, coagulation and upgrading. It has formed its own distinctive brand in terms of professional quality, educational and teaching objectives, classroom teaching effectiveness, faculty building, quality of personnel training, and has been widely recognized by the community. Local colleges and universities must make full use of their special geographical advantages and carry out specialty settings, specialty planning and specialty construction in a "point-to-face" way in accordance with the special needs of the special industries and trades in the region, so as to form the specialty structure of "people without me", "people with my superiority" and "people with my superiority" and gradually cultivate them. It develops into a professional characteristic brand with regional characteristics and achieves "dislocation competition" with other universities. In order to better carry out the construction of specialty characteristic brand, local colleges and universities should also formulate the medium and long-term development plan of specialty characteristic brand, introduce and train the Faculty of specialty construction, at the same time, reform the mode of personnel training, strengthen the construction of new teaching materials, reform the teaching content and practice teaching, and construct the course to adapt to the development of regional economy and society. By integrating the policies and measures of the state, the government, the competent departments of education and the universities, the curriculum system should be strengthened and the special brand majors should be given preferential support in terms of funds input, enrollment targets and teaching reform projects. In addition, local colleges and universities should make full use of all kinds of awards, subsidies and subsidies ${ }^{[12]}$. The guiding role of the loan funds is to encourage enterprises and individuals to set up special grants for special brand majors, and so on, so as to attract outstanding students to study brand majors with scarce and arduous characteristics. Finally, the core competitiveness of local colleges and universities will be formed.

\section{CONCLUSION}

The state promotes the construction of "double firstclass" universities, although it is aimed at high-level universities, but local colleges and universities should also play a role in this round of construction, "double first-class" universities in the discipline and professional construction experience is worth learning. Local colleges and universities should find their own shortcomings in the comparative analysis of their professional construction with "double-firstclass" universities. By means of scientific proof, characteristic specialty construction and evaluation of specialty construction, local colleges and universities can enhance the connotation of specialty construction.

\section{REFERENCES}

[1] Xiong Si Dong. China's higher education is leading the future [N] China Education newspaper, 2018-3-9 (Fifth Edition).

[2] Hou Airong. The logic and mechanism of professional setting in Applied Undergraduate Universities [J]. higher education in Jiangsu.2016 (6): 84-87.

[3] Liu Gonghui. Logic and Approach of "Double First-class" Construction of Local University [J].China Higher Education, 2017 (8): 32-36

[4] Zheng Jibing. Look at the predicament and outlet of university specialty construction from the perspective of talent cultivation program [J]. Jiangsu higher education.2013 (1): 44-48

[5] Xu Liqing, Cui Yanqun. Provincial co ordination in the specialty setting of local colleges and universities, [J]. Education Development Research2016 (7): 85-92.

[6] $\mathrm{Hu}$ Yan. Research on the specialty construction of universities. [J]. Jiangsu higher education, 2016 (6): 83-85.

[7] He Xiangyi. Probe into the lag of specialty setting in local colleges and universities [J].Heilongjiang Higher Education Research, 2012 (11): 162-166.

[8] Zhou Jiahe. Probe into the Construction of Specialty in Local Applied Universities [J]. Teaching in China University, 2017 (12): 43-49.

[9] Qiu Xiaojie. A study on the orientation of regional economy and specialty construction in local universities [J].China Adult Education, 2008 (5): 25-27.

[10] Ren Changyin. A review of the research on specialty evaluation in Chinese universities [J]. Journal of Hubei University of Economics (Humanities and Social Sciences), 2014 (6): 115-116. 
[11] Hu Yan et al. A study of specialty construction in universities. [J]. higher education in Jiangsu, 2016 (6): 82-85.

[12] Chen Aizhi. Current situation and Countermeasures of undergraduate professional structure in Fujian province [J]. education review, 2015 (1): 144-149. 